\title{
A contribution to the karyosystematics of the planthopper families Dictyopharidae and Fulgoridae (Hemiptera: Auchenorrhyncha)
}

\author{
VALENTina G. KUZNETSOVA ${ }^{1}$, AnNA MARYAŃSKA-NADACHOWSKA ${ }^{2}$ and AlEXANDER F. EMELJANOV ${ }^{1}$ \\ ${ }^{1}$ Zoological Institute, Russian Academy of Sciences, Universitetskaya nab. 1, 199034 St. Petersburg, Russia; \\ e-mails: karyo@zin.ru; hemipt@zin.ru \\ ${ }^{2}$ Institute of Systematics and Evolution of Animals, Polish Academy of Sciences, Sławkowska 17, 30-016 Kraków, Poland; \\ e-mail: maryanska@isez.pan.krakow.pl
}

Key words. Hemiptera, Auchenorrhyncha, Dictyopharidae, Fulgoridae, karyotypes, sex chromosomes, testes, ovaries, evolution, systematics

\begin{abstract}
The chromosome complements of thirteen species of the planthopper family Dictyopharidae are described and illustrated. For each species, the structure of testes and, on occasion, ovaries is additionally outlined in terms of the number of seminal follicles and ovarioles. The data presented cover the tribes Nersiini, Scoloptini and Dictyopharini of the subfamily Dictyopharinae and the tribes Ranissini, Almanini, and Orgeriini of the Orgeriinae. The data on the tribes Nersiini and Orgeriini are provided for the first time. Males of Hyalodictyon taurinum and Trimedia $\mathrm{cf}$. viridata (Nersiini) have $2 \mathrm{n}=26+\mathrm{X}$; Scolops viridis, S. sulcipes, and $S$. abnormis (Scoloptini) 2n = 36 +X; Callodictya krueperi (Dictyopharini) $2 \mathrm{n}=26+\mathrm{X}$; Ranissus edirneus and Schizorgerius scytha (Ranissini) $2 \mathrm{n}=26+\mathrm{X}$. Males of Almana longipes and Bursinia cf. genei (Almanini) have $2 \mathrm{n}=26+\mathrm{X}$ and $2 \mathrm{n}=24+\mathrm{XY}$, respectively. The latter chromosome complement was not recorded previously for the tribe Almanini. Males of Orgerius ventosus and Deserta cf. bipunctata (Orgeriini) have $2 \mathrm{n}=26+$ X. The testes of males of A. longipes and B. cf. genei each have 4 seminal follicles, which is characteristic of the tribe Almanini. Males of all other species have 6 follicles per testis. When the ovaries of a species were also studied, the number of ovarioles was coincident with that of seminal follicles. For comparison, Capocles podlipaevi $(2 \mathrm{n}=24+\mathrm{X}$ and 6 follicles per testis in males) from the Fulgoridae, the sister family to Dictyopharidae, was also studied. We supplemented all the data obtained with our earlier observations on Dictyopharidae. The chromosomal complement of $2 n=28+X$ or that of $2 \mathrm{n}=26+\mathrm{X}$ and 6 follicles per testis are suggested to be the ancestral condition among Dictyopharidae, from which taxa with various chromosome numbers and testes each with 4 follicles have differentiated.
\end{abstract}

\section{INTRODUCTION}

The relatively large planthopper family Dictyopharidae Spinola, 1839 consists of two subfamilies: Dictyopharinae with some 300 species, 70 genera, 11 tribes and Orgeriinae with 192 species, 37 genera, 4 tribes (Emeljanov, 1980, 2007). The family is distributed world-wide with the exception of boreal regions. The classification and relationships within Dictyopharinae are still poorly known, whereas those within Orgeriinae are well supported by morphological (Emeljanov, 1980), incomplete cytogenetic (Kuznetsova, 1985), and preliminary molecular (Emeljanov et al., 2005) data.

So far, the chromosome complements of 34 dictyopharid species belonging to the tribes Dictyopharini, Scoloptini, and Orthopagini of the Dictyopharinae and the tribes Ranissini and Almanini of the Orgeriinae have been described (Kuznetsova, 1985; Kirillova, 1986; Tian et al., 2004). The species studied have two sex-determining mechanisms (XX/X0 and XX/XY) and a diploid chromosome number in males ranging from $2 \mathrm{n}=26$ to 37 , with $2 \mathrm{n}=36+\mathrm{X}, 2 \mathrm{n}=28+\mathrm{X}$, and $2 \mathrm{n}=26+\mathrm{X}$ in the Dictyopharinae, and $2 \mathrm{n}=26+\mathrm{X}$ and $2 \mathrm{n}=24+\mathrm{XY}$ in the Orgeriinae. The chromosome complement of $2 n=28+X$ is proposed as the ancestral and the other complements as derivatives in the family Dictyopharidae (Kuznetsova, 1985).
Auchenorrhynchan chromosomes are holokinetic (Halkka, 1959; Kuznetsova, 1985). Theoretically, this should favour fragmentations and translocations, since the spindle microtubules can universally attach to a kinetochore. In spite of this, available data indicate remarkable karyotype stability at the tribal level within the family, at least in the subfamily Orgeriinae.

A similar trend is recorded for testis structure, which is constant at the taxonomic levels of tribe and subfamily in the Dictyopharidae. In all Dictyopharinae and the tribe Ranissini of the Orgeriinae, males have testes each with 6 follicles, whereas in the more advanced tribe Almanini, males have 4 follicles per testis (Kuznetsova, 1985). The phylogenetic importance of this character has been repeatedly demonstrated and discussed for Auchenorrhyncha (Emeljanov \& Kuznetsova, 1983; Kirillova, 1989; D’Urso et al., 2005).

In this study, we describe chromosome complements of thirteen dictyopharid species, representing the tribes Nersiini (two species), Scoloptini (three), Dictyopharini (one), Ranissini (two), Almanini (two), and Orgeriini (three), and, additionally, one representative of the family Fulgoridae, sister to the Dictyopharidae. The data on the tribes Nersiini and Orgeriini are provided for the first time. For each species, we also report the structure of testes and, on occasion, ovaries in terms of the number of 
TABLE 1. Systematic placement of the species (after Emeljanov, 1980, 2004), locality and number of specimens studied.

\begin{tabular}{|c|c|c|}
\hline Species & Locality & Number of males/females studied \\
\hline \multicolumn{3}{|l|}{ Dictyopharinae: Nersiini } \\
\hline 1. Hyalodictyon taurinum Stål, 1862 & French Guyana & $1 / 0$ \\
\hline 2. Trimedia $\mathrm{cf}$. viridata Stål, 1862 & French Guyana & $1 / 0$ \\
\hline \multicolumn{3}{|l|}{ Scoloptini } \\
\hline 3. Scolops (Belonocharis) abnormis Ball, 1902 & USA, California & $3 / 0$ \\
\hline 4. S. (Scolops) sulcipes Say, 1825 & USA, Ilinois & $1 / 0$ \\
\hline 5. S. (S.) viridis Ball \& Hartzell, 1902 & USA, California & $2 / 0$ \\
\hline \multicolumn{3}{|l|}{ Dictyopharini } \\
\hline 6. Callodictya krueperi Fieb., 1872 & Bulgaria & $1 / 0$ \\
\hline \multicolumn{3}{|l|}{ Orgeriinae: Ranissini } \\
\hline 7. R. (Ranissus) edirneus Dlab., 1957 & Greece & $1 / 0$ \\
\hline 8. Schizorgerius scytha Osh., 1913 & Bulgaria & $1 / 1$ \\
\hline \multicolumn{3}{|l|}{ Almanini } \\
\hline 9. Almana longipes Duf., 1849 & Spain & $2 / 3$ \\
\hline 10. Bursinia cf. genei Duf., 1849 & Spain & $1 / 1$ \\
\hline \multicolumn{3}{|l|}{ Orgeriini } \\
\hline 11. Deserta bipunctata Ball, 1909 & USA, California & $1 / 3$ \\
\hline 12. Orgerius (Opsigonus) ventosus Ball \& Hartzell, 1922 & USA, California & $3 / 0$ \\
\hline 13. O. (Orgerius) rhyparus Stål., 1859 & USA, California & $1 / 0$ \\
\hline \multicolumn{3}{|l|}{ Fulgoridae: Strongylodematinae: Capocleini } \\
\hline 14. Capocles podlipaevi Em., 2007 & South Africa & $2 / 0$ \\
\hline
\end{tabular}

seminal follicles and ovarioles, respectively. Our new data conflict in part with the earlier accepted assumption that chromosome complements within the subfamily Orgeriinae are extremely stable at the tribal level. Nevertheless, this character as well as the number of testicular follicles in males appear to be good markers in phylogenetic sister group analysis of higher taxonomic categories within the Dictyopharidae. The ancestral chromosome complement of the family is discussed.

\section{MATERIAL AND METHODS}

The information on localities from which the species were collected and the number of males and females analysed is given in Table 1. The voucher specimens and chromosome slides are deposited in the Zoological Institute of the Russian Academy of Sciences, St. Petersburg, Russia.

Specimens were fixed in Carnoy's fixative (ethanol/acetic acid, $3: 1$ ). All chromosome preparations were from testes and ovaries. Separated seminal follicles were squashed on a slide in $45 \%$ acetic acid; the coverslip was removed after freezing with dry ice and the preparation was allowed to dry. The preparations were first analysed under a phase contrast microscope at $400 \times$. The best chromosome spreads were stained following a standard Feulgen-Giemsa procedure (Grozeva \& Nokkala, 1996) and photographed. When spermatogonial or oogonial complements were available a karyogram was constructed by arranging the chromosomes in order of decreasing size.

\section{RESULTS}

The diploid karyotype of males and the number of testicular follicles and ovarioles of each species studied as well as the currently available evidence on the families Dictyopharidae and Fulgoridae are presented in Tables 2 and 3, respectively. The nomenclature is after Emeljanov (1980, 2004).

\section{DICTYOPHARIDAE \\ DICTYOPHARINAE \\ NERSIINI}

Hyalodictyon taurinum Stål: 6 follicles per testis $(6 \mathrm{f}.) ; 2 \mathrm{n} 0^{\star}=$ $26+\mathrm{X}$ (Fig. 1a, b)

Trimedia cf. viridata Stål: 6f.; $2 \mathrm{n} \widehat{\widehat{t}}=26+\mathrm{X}$ (Fig. 2)

In males of both species studied, testes consisted of 6 follicles each, elongate in shape and covered by a red membrane. Only meiotic pictures were available for analysis. The chromosome complements of these species appeared similar to each other. Metaphase I (MI) cells of $H$. taurinum showed 13 autosomal bivalents and a univalent $\mathrm{X}$ chromosome suggesting $2 \mathrm{n}=26+\mathrm{X}$ (Fig. 1a). Autosomal bivalents constitute a decreasing size series (from AA1 down to AA13), however one bivalent (AA1) stands out because of its larger size. The $\mathrm{X}$ chromosome univalent is close in size to the smallest half-bivalents. Shown in Fig. 1b are two daughter metaphase II (MII) cells with $n=13$ (only autosomes) and $n=14$ (autosomes plus X chromosome), respectively. Similarly, 13 autosomal bivalents and a univalent $\mathrm{X}$ chromosome were observed at the diplotene/diakinesis stages of $T$. cf. viridata (Fig. 2). The bivalents usually formed only one chiasma, however two or three chiasmata might at times be present in the larger bivalents.

\section{SCOLOPTINI}

Scolops viridis Ball \& Hartzell: 6 f.; 2n $\widehat{0}=36+\mathrm{X}$ (Fig. 3).

S. sulcipes Say: $6 \mathrm{f}$; $2 \mathrm{n} \sigma^{*}=36+\mathrm{X}$ (not shown).

S. abnormis Ball: 6 f.; 2n $0 \hat{~}=36+\mathrm{X}$ (Fig. 4).

In males of the three species studied, testes consisted of 6 follicles each, elongate in shape and covered by a red membrane. The species were found to have 18 autosomal bivalents and a univalent $\mathrm{X}$ chromosome in the MI cells 


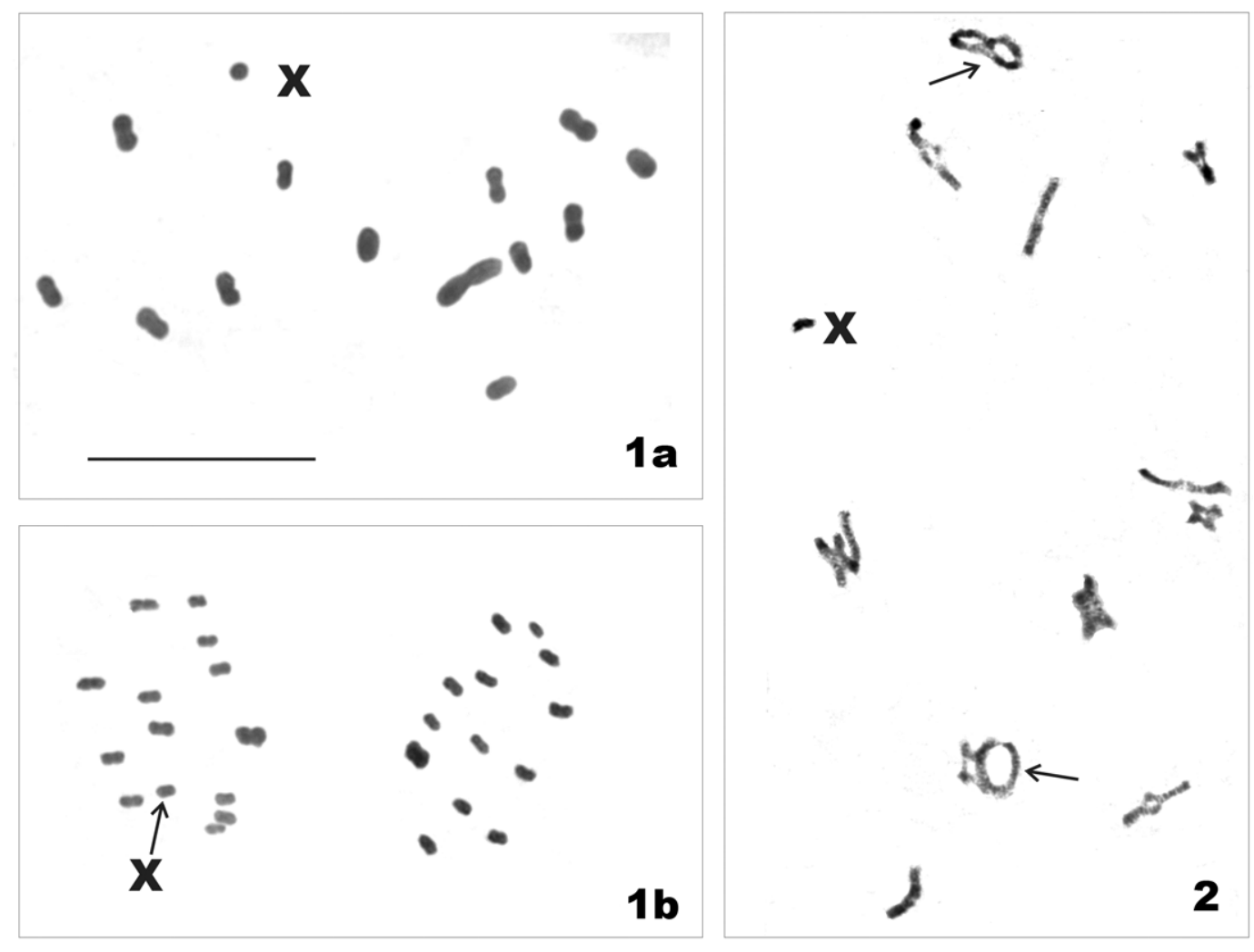

Figs 1, 2. Male meiotic chromosomes of Dictyopharidae. 1a, b - Hyalodictyon taurinum, a - metaphase I, $\mathrm{n}=13+\mathrm{X} ; \mathrm{b}-$ two metaphase II complements, one with $\mathrm{n}=13+\mathrm{X}$ (left) and the other with $\mathrm{n}=13$ (right); 2 - Trimedia $\mathrm{cf}$. viridata, diplotene/diakinesis, $n=13+X$; arrows indicate bivalents with three (upper) and two (lower) chiasmata. Bar $=10 \mu \mathrm{m}$. Scale bar on Fig. 1a refers to Figs $1 \mathrm{a}, \mathrm{b}$ and 2 .

consistent with $2 \mathrm{n}=37$ and an $\mathrm{X} 0$ sex-determining system. Figs 3 and 4 show MI of $S$. viridis and $S$. abnormis, respectively. At this stage, chromosome complements of both species appear similar to each other. The autosomal bivalents constitute a decreasing size series; none of which are very large or very small. The $\mathrm{X}$ chromosome univalent is similar in size to the smaller half-bivalents.

\section{DICTYOPHARINI}

Callodictya krueperi Fieb.: 6 f.; 2nô $=26+$ X (Fig. 5)

In the only male available, testes each consisted of 6 follicles. In the spermatogonial cells there were 27 chromosomes. This chromosome number suggests $2 \mathrm{n}=26+$ $\mathrm{X}$, however, we failed to distinguish a sex chromosome.

\section{ORGERIINAE}

\section{RANISSINI}

Schizorgerius scytha Osh.: 6 f.; 6 ovarioles per ovary (6 ov.);

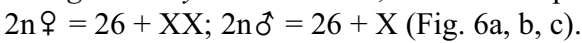

R. edirneus Dlab.: 6 f.; $2 \mathrm{n} \widehat{0}=26+\mathrm{X}$ (not shown).

In males of both species, testes each consisted of 6 follicles, elongate in shape and covered by a red membrane. In the first species, the ovaries consisted each of 6 rounded ovarioles. Females of the second species were not examined. These species have a similar karyotype. Fig. 6a and 6b show an oogonial mitotic metaphase of $S$. scytha with 28 chromosomes and a karyogram prepared from the same metaphase, respectively. In this karyotype two autosomes stand out from the rest of the chromo- somes because of their very large size. This pair of autosomes (AAI) is about 3-4 times larger than the second pair of autosomes (AA2). Each of the largest autosomes shows a clear subterminal constriction probably representing a nucleolar organizer region (NOR). The X chromosomes could not be differentiated from the autosomes since none of the chromosomes appeared more condensed or positively heteropycnotic at this stage. Male meiotic metaphase I (Fig. 6c) showed a chromosome number of 13 pairs of autosomes and a univalent $\mathrm{X}$ chromosome. As in mitotic metaphases, one of the autosomal pairs is larger than the other bivalents, however, due to a high degree of condensation no gap is visible in this largest bivalent, and its greater size is not nearly as marked as in mitotic preparations.

\section{ALMANINI}

Almana longipes Duf.: 4 f.; 4 ov.; 2n $\widehat{0}=26+\mathrm{X}$ (Fig. 7a, b, c, d).

In the females and males studied, ovaries and testes each consisted of 4 ovarioles and 4 follicles, respectively. Ovarioles were round in shape, whereas follicles were elongate and covered by a red membrane. Fig. 7a shows a spermatogonial mitotic metaphase with 27 chromosomes, including a pair of very long autosomes (AA1). Fig. 7b shows a karyogram prepared from the same metaphase. From these figures we notice that every homologue of the longest autosome pair has a prominent subterminal constriction. This constriction could be related to an NOR. 


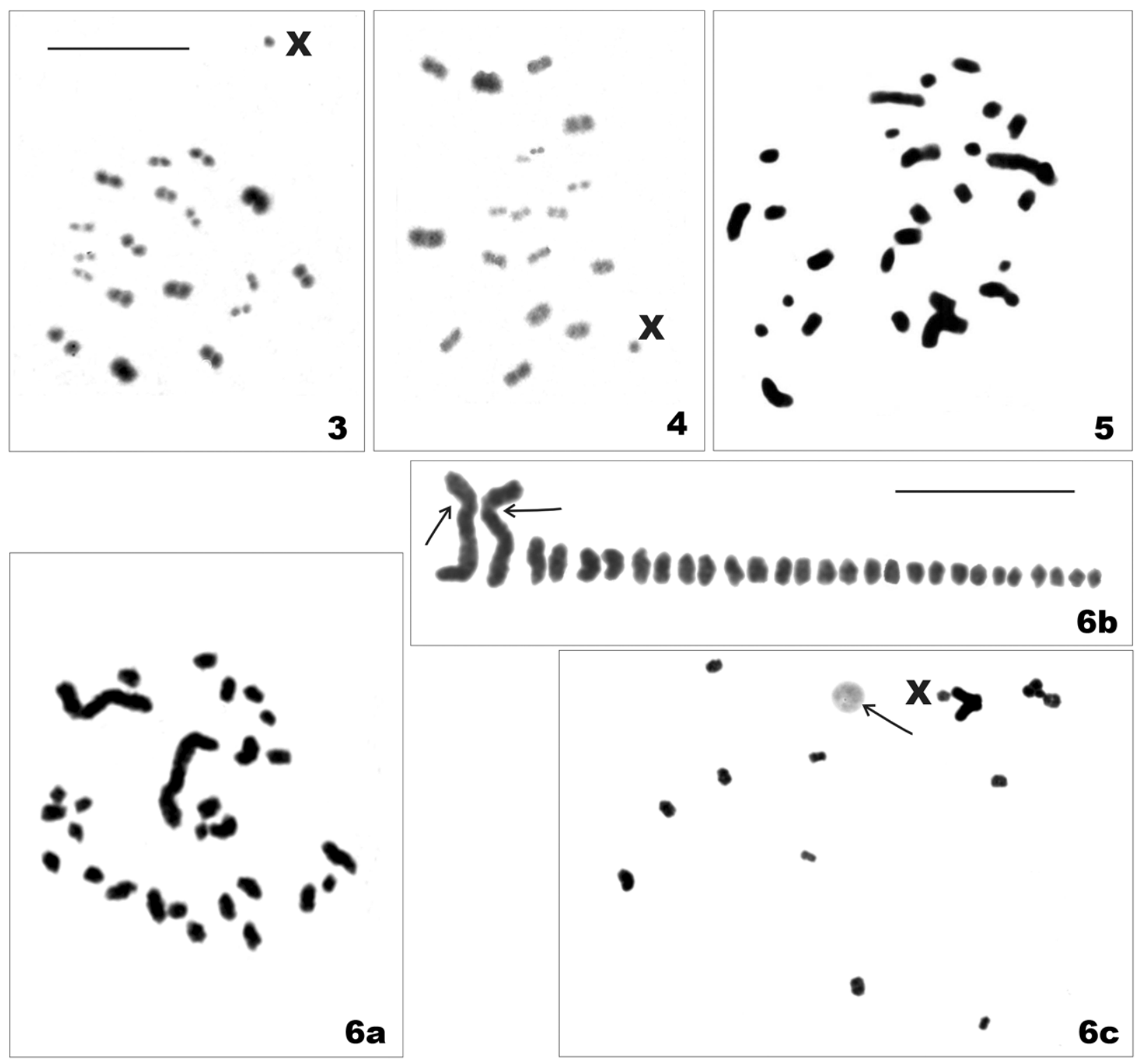

Figs 3-6. Meiotic and mitotic chromosomes of males and females of Dictyopharidae. 3 - Scolops viridis, male metaphase $\mathrm{I}, \mathrm{n}=18$ $+\mathrm{X} ; 4$ - Scolops abnormis, male metaphase I, $\mathrm{n}=18+\mathrm{X} ; 5-$ Callodictya krueperi, male mitotic metaphase, 2n $=27 ; 6 \mathrm{a}, \mathrm{b}, \mathrm{c}-$ Schizorgerius scytha, a - female mitotic metaphase, $2 \mathrm{n}=28 ; \mathrm{b}$ - karyogram prepared from the same metaphase, $2 \mathrm{n}=28 ; \mathrm{c}-$ male metaphase I, $\mathrm{n}=13+\mathrm{X}$. The arrows indicate gaps, probably NORs (Fig. 6b) and a nucleolus (Fig. 6c). Bar $=10 \mu \mathrm{m}$. Scale bar on Fig. 3 refers to Figs 3, 4, and 6c. Scale bar on Fig. 6b refers to Figs 5, 6a, and 6b.

The AA1 pair is about $4-5$ times longer than the AA2 pair. The autosomes AA2-AA13 represent a decreasing size series, and the $\mathrm{X}$ chromosome looks similar in size to the smaller autosomes. Male meiotic metaphase I (Fig. 7c) confirmed the karyotype found in mitotic metaphases and revealed 13 autosomal bivalents and an X univalent. The latter behaves as a laggard on the anaphase I (AI) spindle (Fig. 7d). Due to a high degree of condensation, no gap is visible in the longest bivalent, either at MI or AI.

Bursinia cf. genei Duf.: 4 f.; 4 ov.; 2nô $=24+$ XY (Fig. 8).

Ovaries and testes each consisted of 4 ovarioles and 4 follicles, respectively. Ovarioles were round in shape, whereas follicles were elongate and covered by a red membrane. Only a few dividing cells were found in the testes. Thirteen bivalents were observed at the diakinesis/metaphase I transition implying the presence of an XY sex-determining system. One of the bivalents was much longer than the others, while the remaining bivalents gradually decreased in size (Fig. 8). None of the bivalents was clearly heteromorphic, thus, the XY bivalent could not be confidently identified.

\section{ORGERIINI}

Deserta cf. bipunctata Ball: 6 f.; 6 ov.; 2not $=26+$ X (Fig. 9a, b).

Ovaries and testes each consisted of 6 ovarioles and 6 follicles, respectively. Ovarioles were round in shape, whereas follicles were elongate and covered by a red membrane. Fig. 9a and $9 \mathrm{~b}$ show diplotene/diakinesis nuclei with 13 autosomal bivalents and a univalent $\mathrm{X}$ 

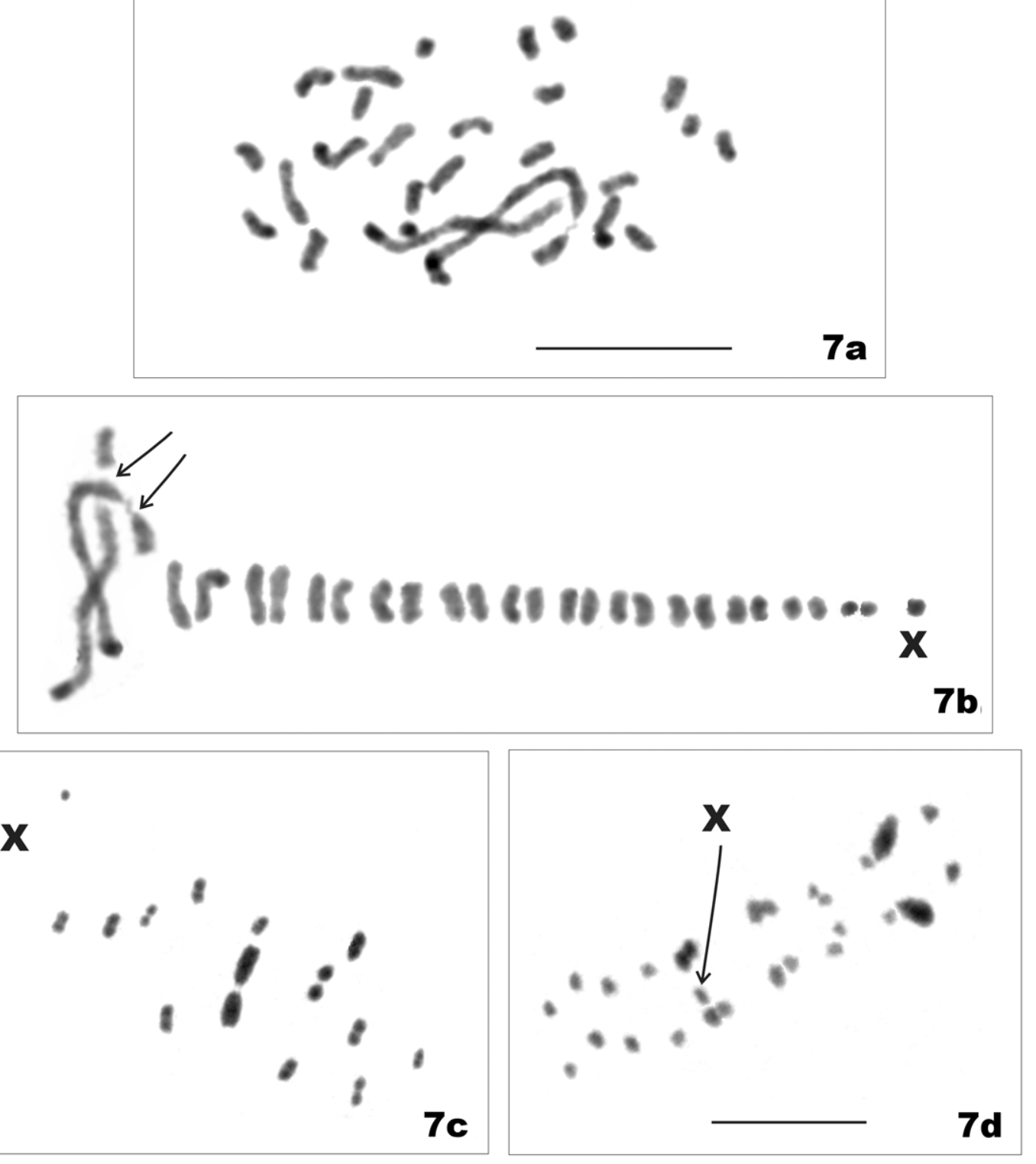

Fig. 7. - Almana longipes, $\mathrm{a}$ - male mitotic metaphase, $2 \mathrm{n}=27 ; \mathrm{b}$ - karyogram prepared from the same metaphase; $\mathrm{c}-$ male metaphase I, $\mathrm{n}=13+\mathrm{X} ; \mathrm{d}-$ male anaphase I. The arrows indicate gaps, probably NORs (Figs $7 \mathrm{~b}$ ). Bar $=10 \mu \mathrm{m}$. Scale bar on Fig. $7 \mathrm{a}$ refers to Fig. $7 \mathrm{a}$ and $7 \mathrm{~b}$; scale bar on Fig. $7 \mathrm{~d}$ refers to Fig. $7 \mathrm{c}$ and $7 \mathrm{~d}$.

chromosome. The pair AA1 is very large, whereas the bivalents AA2-AA13 constitute a decreasing size series. The X univalent looks similar in size to the smallest halfbivalents. The longest autosomal pair shows a discontinuity in one homologue (not shown), and a large nucleolus is frequently associated with this gap (Fig. 9a) or positioned alongside it (Fig. 9b). This may indicate the location of an NOR, which remains active during late prophase I. The autosomal bivalents have one interstitial or terminal chiasma, however, in some cells the largest bivalent is ring-shaped, which indicates the occurrence of two chiasmata (Fig. 9b).

Orgerius rhyparus Stål: $6 \mathrm{f}$; $2 \mathrm{n}{ }^{\star}=26+\mathrm{X}$ (not shown). Orgerius ventosus Ball \& Hartzell: 6 f.; 2nơ $=26+\mathrm{X}$ (Fig. 10).
In males of both species, testes each consisted of 6 follicles, elongate in shape and covered by a red membrane. The species have similar karyotypes. Fig. 10 shows a condensed metaphase I of $O$. ventosus with 13 autosomal bivalents and a univalent $\mathrm{X}$ chromosome. The AA1 pair is about twice as long as the AA2 pair. The bivalents AA2-AA13 constitute a decreasing size series, and the $\mathrm{X}$ univalent is similar in size to the smallest half-bivalents.

FULGORIDAE

\section{STRONGYLODEMATINAE}

\section{CAPOCLEINI}

Capocles podlipaevi Em.: 5/6 f.; 4/6 f.; $2 \mathrm{n} \widehat{ } \hat{~}=24+\mathrm{X}$ (not shown). 


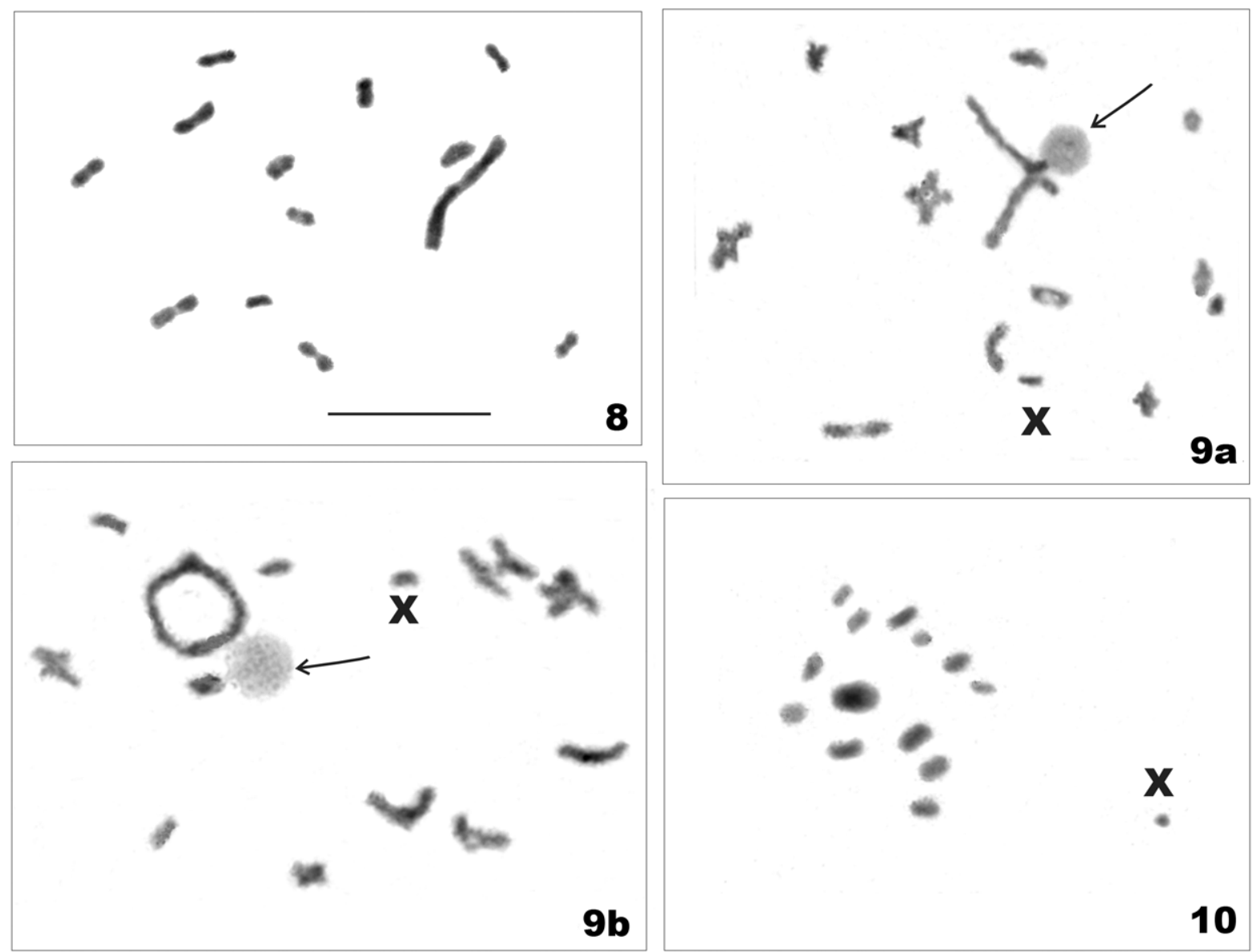

Figs 8-10. Male meiotic chromosomes of Dictyopharidae. 8 - Bursinia cf. genei, metaphase I, $\mathrm{n}=13 ; 9 \mathrm{a}, \mathrm{b}-$ Deserta bipunctata, diplotene/diakinesis, $\mathrm{n}=13+\mathrm{X}$; the arrows indicate nucleoli (Fig. 9a, b); 10 - Orgerius ventosus, metaphase $\mathrm{I}, \mathrm{n}=13+\mathrm{X} . \mathrm{Bar}=10$ $\mu \mathrm{m}$. Scale bar on Fig. 8 refers to Figs 8, 9a, b and 10.

The two males studied were polymorphic for the number of testicular follicles. One male had 6 and 5 follicles, whereas the other had 6 and 4 in different testes, respectively. Metaphase I cells have 12 pairs of autosomes and the univalent $\mathrm{X}$ chromosome suggesting a diploid chromosome complement of $2 n=24+X$.

\section{DISCUSSION}

The diversity of chromosome numbers, sex-determining mechanisms, and number of testicular follicles in the family Fulgoridae

The chromosome complement in the family Fulgoridae is relatively very variable both in diploid chromosome number and sex-determining mechanism (Table 2).
Taking into account the new data presented here, in a total of 5 species belonging to the genera Capocles, Lycorma and Limois there are three distinct chromosome complements. Lycorma delicatula and C. podlipaevi have $2 n=22+X$ and $2 n=24+X$, respectively. It is significant that these chromosome numbers have never been recorded in the very similar and phylogenetically close family Dictyopharidae (Emeljanov, 1979; Yeh et al., 2005), which is much better studied in respect of karyotypes (Table 3). Furthermore, though both of the representatives of the relatively advanced fulgorid genus Limois studied share $2 \mathrm{n}=24+\mathrm{XY}$ with the advanced dictyopharid tribe Almanini (Table 3), the Limois chromosome complement is in fact quite different from that of

TABLE 2. List of the Fulgoridae species studied (systematic placement after Emeljanov, 2004), male diploid chromosome numbers, number of follicles per testis and ovarioles per ovary. The absence of data is denoted as "-".

\begin{tabular}{|c|c|c|c|c|}
\hline Species & $2 n \sigma^{\pi}$ & Number of follicles per testis & Number of ovarioles per ovary & References \\
\hline Capocles podlipaevi Em. & $24+X$ & $5 / 6 ; 4 / 6^{\mathrm{a}}$ & - & This study \\
\hline Dorysarthrus sumakovi Osh. & - & - & 5 & Kaplin, 1985 \\
\hline Limois emelianovi Osh. & $24+X Y$ & 6 & - & Kuznetsova, 1985 \\
\hline Limois kikuchii Kato & $24+X Y$ & - & - & Tian et al., 2004 \\
\hline Lycorma delicatula (White) & $22+X$ & - & - & Tian et al., 2004 \\
\hline
\end{tabular}

${ }^{a}$ Number of follicles varied between testes in each of the two males studied. 
TABLE 3. List of the Dictyopharidae species studied (systematic placement after Emeljanov, 1980), male diploid chromosome numbers, number of follicles per testis and ovarioles per ovary. The absence of data is denoted as "-".

\begin{tabular}{|c|c|c|c|c|}
\hline Species & $2 n \delta$ & $\begin{array}{c}\text { Number of } \\
\text { follicles per testis }\end{array}$ & $\begin{array}{c}\text { Number of } \\
\text { ovarioles per ovary }\end{array}$ & References \\
\hline \multicolumn{5}{|l|}{ DICTYOPHARINAE } \\
\hline \multicolumn{5}{|l|}{ Nersiini } \\
\hline Hyalodictyon taurinum Stål & $26+X$ & 6 & - & this study \\
\hline Rhynchomitra cubanensis Mel. & - & 6 & - & Kuznetsova \& Kirillova, 1990 (as Rh. cubana) \\
\hline Trimedia cf. viridata Stål & $26+X$ & 6 & - & this study \\
\hline \multicolumn{5}{|l|}{ Dictyopharini } \\
\hline Callodictya krueperi Fieber & $27^{\mathrm{a}}$ & 6 & - & this study \\
\hline Dictyophara (Chanithus) avocetta Osh. & $28+X$ & 6 & - & Kuznetsova, 1985 \\
\hline D. (Chanithus) pannonica Germ. & $28+X$ & 6 & - & Kuznetsova, 1985 \\
\hline D. (Chanithus) scolopax Osh. & $28+X$ & 6 & - & Kuznetsova, 1985 \\
\hline D. (Chanithus) kaszabi Dlab. & $28+\mathrm{X}$ & 6 & - & Kuznetsova, 1985 \\
\hline D. (Euthremma) multireticulata M. R. & $28+X$ & 6 & - & Kuznetsova, 1985 \\
\hline \multirow[t]{2}{*}{ D. (s.str.) europaea L. } & $28+\mathrm{X}$ & 6 & - & Kuznetsova, 1985; \\
\hline & - & - & 6 & Emeljanov \& Kuznetsova, 1983 \\
\hline D. (s.str.) koreana Mats. & $28+X$ & - & - & Tian et al., 2004 (as Centromeria manchurica Kato) \\
\hline Philotheria sp. & - & 6 & - & Kuznetsova \& Kirillova, 1990 \\
\hline Raivuna pallida Donov. & $28+X$ & 6 & - & Bhattacharya \& Manna, 1973 (as Dictyophara) \\
\hline R. sinica Walker & $26+X$ & - & - & Tian et al., 2004 (as Dictyophara) \\
\hline R. striata Osh. & $28+\mathrm{X}$ & 6 & - & Kuznetsova, 1985 \\
\hline \multicolumn{5}{|l|}{ Orthopagini } \\
\hline Saigona ussuriensis Leth. & $28+X$ & - & - & Kuznetsova, 1985 \\
\hline Saigona sp. ${ }^{\mathbf{b}}$ & $26+X$ & - & - & Tian et al., 2004 \\
\hline \multicolumn{5}{|l|}{ Scoloptini } \\
\hline Scolops (Belonocharis) abnormis Ball. & $36+X$ & 6 & - & this study \\
\hline S. (s. str.) sulcipes Say & $36+X$ & - & - & Halkka, 1964; this study \\
\hline S. (s. str.) viridis Ball \& Hartzell & $36+X$ & 6 & - & this study \\
\hline \multicolumn{5}{|l|}{ ORGERIINAE } \\
\hline \multicolumn{5}{|l|}{ Ranissini } \\
\hline Elysiaca chomutovi Osh. & $26+X$ & 6 & - & Kuznetsova, 1985 \\
\hline E. elliptica Osh. & $26+X$ & - & - & Kuznetsova, 1985 \\
\hline E. oshanini Em. & $26+X$ & - & - & Kuznetsova, 1985 \\
\hline E. sclerosa Em. & $26+X$ & 6 & - & Kuznetsova, 1985 \\
\hline Parorgerius platypus Fieb. & $26+X$ & 6 & - & Kuznetsova, 1985 \\
\hline Ranissus (s.str.) edirneus Dlab. & $26+X$ & 6 & - & this study \\
\hline Ranissus sp. ${ }^{\mathrm{c}}$ & $26+X$ & 6 & - & Kuznetsova, 1985 \\
\hline Schizorgerius scytha Osh. & $26+X$ & 6 & 6 & this study \\
\hline Sphenocratus hastatus Osh. & $26+X$ & 6 & - & Kuznetsova, 1985 \\
\hline \multicolumn{5}{|l|}{ Almanini } \\
\hline Almana longipes Duf. & $26+X$ & 4 & 4 & this study \\
\hline Bursinia genei Duf. & - & 4 & - & Kuznetsova \& Kirillova, 1990 (as Bursinia sp.) \\
\hline B. cf. genei Duf. & $24+\mathrm{XY}$ & 4 & 4 & this study \\
\hline Haumavarga fedtschenkoi Osh. & $24+\mathrm{XY}$ & 4 & - & Kuznetsova, 1985 \\
\hline Kumlika desertorum Osh. & - & - & 4 & Kaplin, 1985 \\
\hline Mesorgerius rysakovi Kuzn. & - & 4 & - & Kuznetsova, 1985 \\
\hline Nymphorgerius skobelevi Osh. & $24+\mathrm{XY}$ & 4 & - & Kuznetsova, 1985 \\
\hline N. alboniger Em. & $24+\mathrm{XY}$ & 4 & - & Kuznetsova, 1985 \\
\hline N. auriculatus Em. & $24+\mathrm{XY}$ & 4 & - & Kuznetsova, 1985 \\
\hline N. bucharicus Osh. & $24+\mathrm{XY}$ & 4 & - & Kuznetsova, 1985 \\
\hline N. dimorphus Osh. & $24+\mathrm{XY}$ & 4 & - & Kuznetsova, 1985 \\
\hline N. ivanovi Kusn. & $24+\mathrm{XY}$ & 4 & - & Kuznetsova, 1985 \\
\hline N. longiceps Osh. & $24+\mathrm{XY}$ & 4 & - & Kuznetsova, 1985 \\
\hline N. medius Osh. & $24+\mathrm{XY}$ & 4 & - & Kuznetsova, 1985 \\
\hline Orgamarella lata Em. & $24+\mathrm{XY}$ & 4 & - & Kuznetsova, 1985 \\
\hline Ototettix jaxartensis Osh. & $24+X Y$ & 4 & - & Kuznetsova, 1985 \\
\hline Repetekia orbicularis Osh. & $24+X Y^{d}$ & 4 & - & Kuznetsova, 1985; \\
\hline & - & - & 4 & Kaplin, 1985 \\
\hline Scirtophaca junatovi Em. & - & 4 & - & Emeljanov \& Kuznetsova, 1983 \\
\hline S. tianshanskyi Osh. & $24+X Y$ & 4 & - & Kuznetsova, 1985 \\
\hline Stephanorgerius zaisanensis Kuzn. & - & 4 & - & Kuznetsova, 1985 \\
\hline Tigrahauda ototettigoides Osh. & $24+\mathrm{XY}$ & 4 & - & Kuznetsova, 1985 \\
\hline T. tiarata Osh. & $24+X Y$ & 4 & - & Kuznetsova, 1985 \\
\hline \multicolumn{5}{|l|}{ Orgeriini } \\
\hline Deserta bipunctata Ball & $26+\mathrm{X}$ & 6 & 6 & this study \\
\hline Orgerius (Opsigonus) ventosus Ball \& Hartzell & $26+X$ & 6 & - & this study \\
\hline O. (s.str.) rhyparus Stål & $26+X$ & 6 & 6 & this study \\
\hline
\end{tabular}



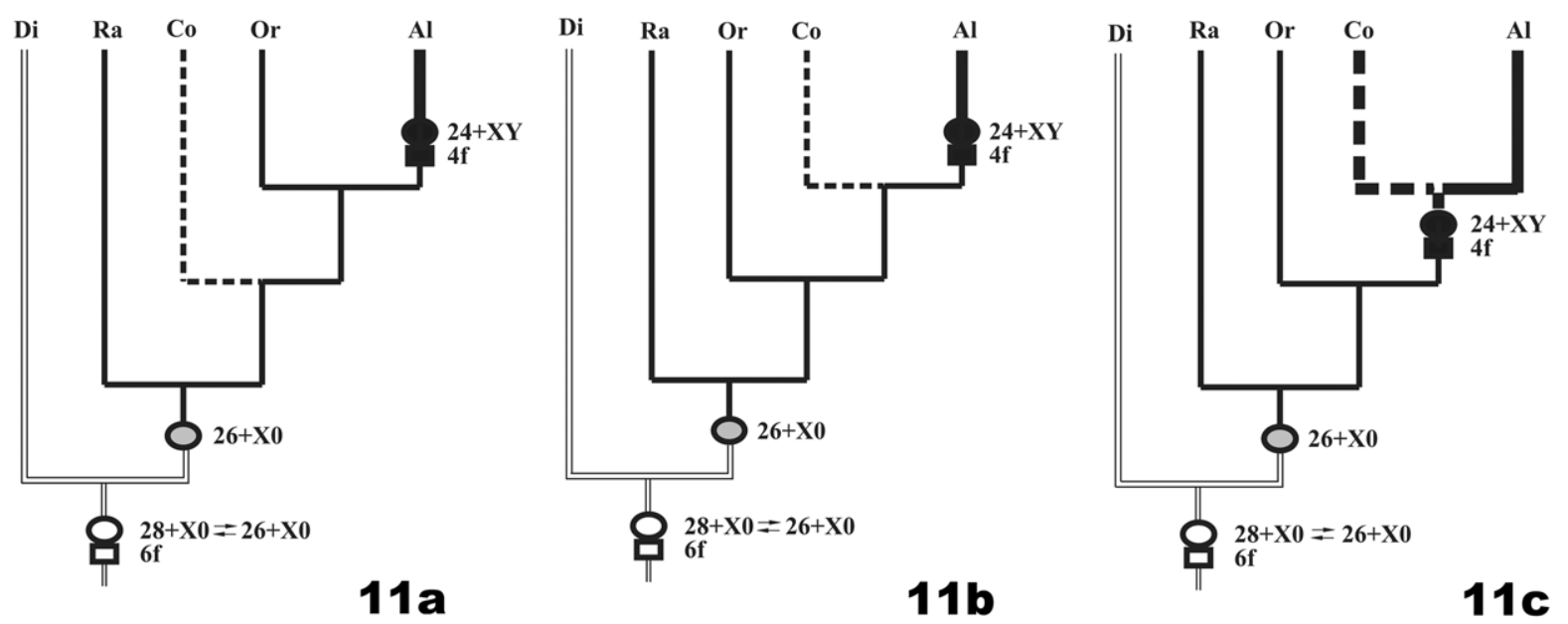

Fig. 11a, b, c. Phylogenetic trees of Dictyopharidae with data on chromosome complements and testicular follicles. a - if Collobocini are a sister tribe to Orgeriini + Almanini, the complement of $2 n=24+X Y$ and testes each with 4 follicles (f) could have risen in Almanini; b, c - if Collobocini are a sister tribe to Almanini, the complement of $2 \mathrm{n}=24+\mathrm{XY}$ and testes each with 4 follicles could have risen in Almanini (b) or in the ancestor of Collobocini + Almanini (c). Di - Dictyopharinae, Ra - Ranissini, Co - Colobocini, Or - Orgeriini, Al - Almanini. The absence of data is designated by interrupted lines; apomorphic states of the characters studied are designated by thick lines.

the Almanini. Evidently, the XY of Almanini represents the neo-XY sex-determining mechanism, whereas that of L. emeljanovi is of different origin (Kuznetsova, 1985). Emeljanov (1979) has identified a number of important morphological differences between Fulgoridae and Dictyopharidae that support the discreteness of these families. Currently, the chromosome evidence, not yet highly representative, also supports their discreteness.

As for the testis structure, it is currently known only for two fulgorid species. Males of L. emeljanovi have 6 follicles per testis, whereas those of $C$. podlipaevi are polymorphic for follicle number (Table 2). In spite of this polymorphism, the latter species most likely has 6 follicles, which seems to be an ancestral number for the superfamily Fulgoroidea as a whole (Emeljanov \& Kuznetsova, 1983).

The diversity of chromosome numbers, sex-determining mechanisms and number of testicular follicles and ovarioles in the family Dictyopharidae

Dictyopharinae

The subfamily Dictyopharinae is subdivided into 9 tribes: Nersiini (28 genera, 111 species), Hastini (4 genera, 13 species), Cleotychini (1 genus, 1 species), Orthopagini (7 genera, 29 species), Aluntiini (4 genera, 10 species), Dictyopharini (21 genera, 80 species), Capenini (3 genera, 7 species), Scoloptini (1 genus, 32 species), and Phylloscelini (1 genus, 4 species) (Emeljanov, 2007, 2008). Taking into account the new data presented here, information on chromosomes is available for the tribes Nersiini (2 genera, 2 species), Orthopagini (1 genus, 2 species), Dictyopharini (3 genera, 11 species), and Scoloptini (1 genus, 3 species) (Table 3). Following are brief discussions of these tribes and the subfamily Dictyopharinae as a whole.

\section{Nersiini}

The tribe Nersiini is restricted to the New World and is suggested to have arrived there in the Pliocene from the Neotropics after the rise of the Isthmus of Panama (Emeljanov, 2007). The species Hyalodictyon taurinum and Trimedia cf. viridata studied here are the first representatives of the tribe for which chromosome evidence is available. Males of these species have similar chromosome complements of $2 \mathrm{n}=26+\mathrm{X}$ with one long pair of autosomes, other autosomes that are much shorter, and a very small X chromosome. They also agree with one another in having 6 follicles per testis, the pattern previously reported for Rhynchomitra cubanensis belonging to the same tribe (Kuznetsova \& Kirillova, 1990) and for all other Dictyopharinae species (Table 3).

\section{Dictyopharini}

The tribe Dictyopharini is distributed throughout the Old World, the Palaearctic fauna of this group being most probably a derivative of the African fauna (Emeljanov, 2007). Besides Callodictya krueperi studied here, 10 more species of the genera Dictyophara (7) and Raivuna (3) are cytogenetically investigated (Table 3 ). We counted 27 chromosomes in the only male of C. krueperi studied, hence this species most likely has a chromosome complement of $2 \mathrm{n}=26+X$. The latter is also characteristic of Raivuna sinica, whereas all other species studied have $2 \mathrm{n}=28+\mathrm{X}$. In all species, C. krueperi included, males have 6 follicles per testis.

\section{Scoloptini}

The Nearctic tribe Scoloptini includes only the genus Scolops with two subgenera (Emeljanov, 2007). The present study has shown a cytogenetic similarity between $S$. viridis and $S$. sulcipes, belonging to the subgenus Scolops, and S. abnormis, belonging to the subgenus Belonocharis. These species have a diploid number of $2 n$ $=37$ in males suggesting $\mathrm{X} 0$ sex-determining system, the 

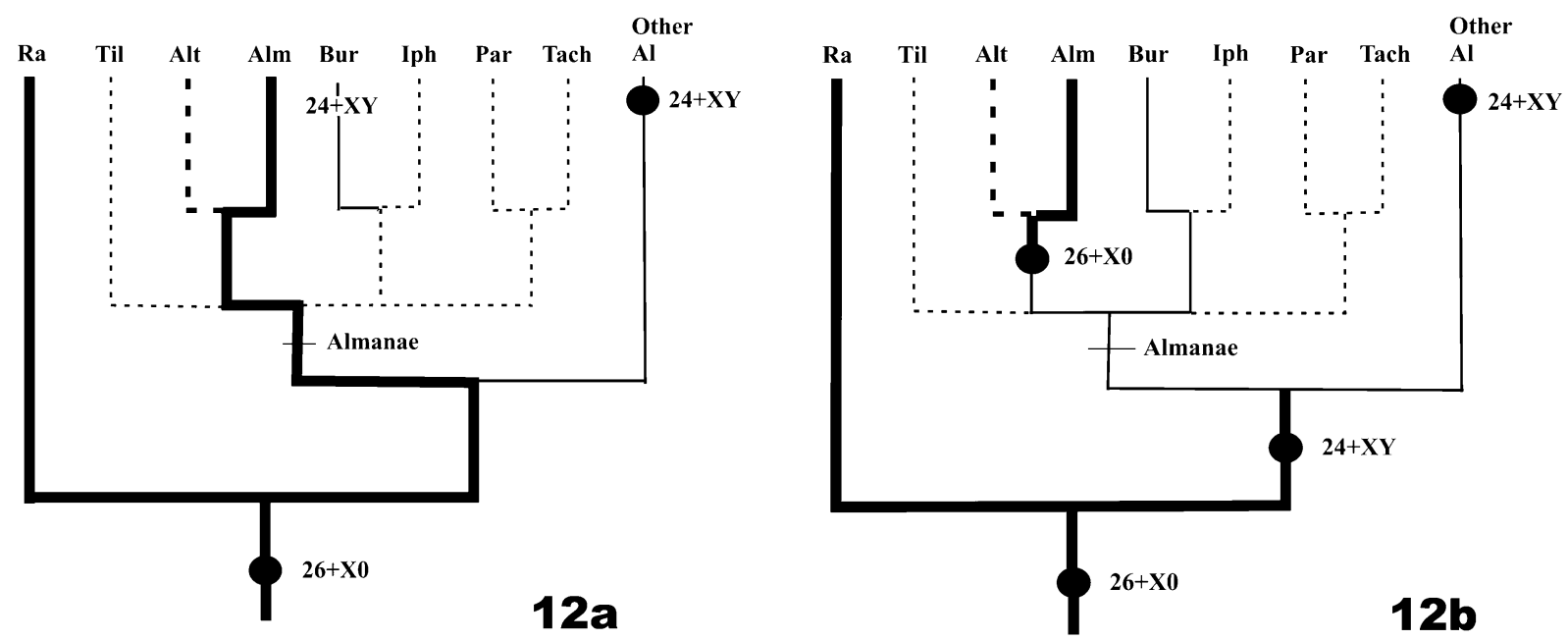

Fig. 12a, b. Phylogenetic trees of the group Almanae with alternative hypotheses for $2 \mathrm{n}=26+\mathrm{X}$ in Almana longipes. a - A. longipes inherited $2 \mathrm{n}=26+\mathrm{X}$ from Ranissini, and thus $2 \mathrm{n}=24+\mathrm{XY}$ independently originated in Bursinia and the common ancestor of the rest of the Almanini; $\mathrm{b}-2 \mathrm{n}=24+\mathrm{XY}$ originated in the common ancestor of the Almanini, and thus $2 \mathrm{n}=26+\mathrm{X}$ in A. longipes is a reversion. Til - Tilimontia, Alt - Almanetta, Alm - Almana, Bur - Bursinia, Iph - Iphicara, Par - Parorgerioides, Tach Tachorga, Ra - Ranissini, Al - Almanini. The absence of data is designated by interrupted lines; plesiomorphic states of the characters studied are designated by thick lines.

characters previously reported for S. sulcipes by Halkka \& Heinonen (1964). The chromosome complements of these species look morphologically uniform. All three karyotypes are known only from meiosis, and the figures of metaphase I show chromosomes gradually decreasing in size and a univalent $\mathrm{X}$ chromosome similar in size to the smaller half-bivalents. Comparison of the chromosome numbers of all the Dictyopharidae (Table 3) shows that the Scolops species have the number, which is most different from the putative ancestral dictyopharid karyotype of $2 \mathrm{n}=28+\mathrm{X}$ (Kuznetsova, 1985; see also below). Evidently, $2 n=36+X$ is the result of fragmentation of autosomes. To date as high a chromosome number as 37 has not been found in any other dictyopharid genera. It is conceivable that this karyotype represents an autapomorphy of the genus Scolops within the subfamily Dictyopharinae. It is noteworthy that males of Scolops species all have 6 follicles per testis.

\section{Orthopagini}

In the tribe Orthopagini only two species, Saigona ussuriensis and Saigona sp., have hitherto been studied. The first species has $2 n=28+X$ and the second $2 n=26$ $+\mathrm{X}$ (Table 3). Judging from the geographical origin of the material studied (China), Saigona sp. is most likely Piela fulgoroides.

\section{Summary}

Taken together, chromosome complements of 18 species of the subfamily Dictyopharinae are currently known. They belong to 7 genera and 4 tribes and demonstrate chromosome complements of $2 \mathrm{n}=36+\mathrm{X}$ ( 3 species, 1 genus), $2 \mathrm{n}=26+X$ ( 5 species, 5 genera, 3 tribes), and $2 \mathrm{n}=28+\mathrm{X}$ (10 species, 3 genera, 2 tribes) (Table 3 ). As can be seen, the complement of $2 \mathrm{n}=28+\mathrm{X}$ predominates, however, this is largely due to the genus Dictyophara, in which it is invariant. Within the genera Raivuna
(Dictyopharini) and Saigona (Orthopagini), $2 \mathrm{n}=28+\mathrm{X}$ occurs along with $2 \mathrm{n}=26+\mathrm{X}$. This testifies that the change-over from one karyotype to the other has proceeded independently in these genera. The internal relationships within the subfamily are not resolved, and the tribe which is closest to the ancestral state remains unclear. Thus, until a reliably justified phylogeny of the Dictyopharinae is constructed, we cannot infer with confidence which karyotype, $2 \mathrm{n}=26+\mathrm{X}$ or $2 \mathrm{n}=28+\mathrm{X}$, is ancestral in this group. Especially as using conventional cytological techniques we could not reveal any cytological markers on the holokinetic chromosomes that could be used to identify each chromosome pair.

Males of all species studied have 6 follicles per testis, which is most likely a characteristic of the subfamily Dictyopharinae. It is noteworthy that this pattern is considered as ancestral in the family Dictyopharidae as a whole (Emeljanov \& Kuznetsova, 1983).

\section{Orgeriinae}

The subfamily Orgeriinae has a holarctic range; it occupies only arid and semiarid regions both in the Palaearctic and Nearctic. Orgeriinae are subdivided into the four tribes: Ranissini (7 genera, 45 species), Colobocini (1 genus, 1 species), Almanini (20 genera, 106 species), and Orgeriini (9 genera, 40 species) (Emeljanov, 1980, 2007). The first three tribes are Palaearctic, whereas Orgeriini are Nearctic. At present, the monophyly of the Orgeriinae casts little if any doubt on this. For construction and substantiation of the phylogeny of this group, three types of character were used: morphological (Emeljanov, 1980), cytogenetical (Kuznetsova, 1985), and molecular (Emeljanov et al., 2005). Of these, however, only morphological information is available for the whole subfamily, whereas the cytogenetical and molecular information is not nearly so complete. 
Considering the new data presented here, chromosome information is currently available for the tribes Ranissini (9 species, 5 genera), Orgeriini ( 3 species, 2 genera), and Almanini (17 species, 10 genera) (Table 3). Following are brief discussions of these tribes and the subfamily Orgeriinae as a whole.

\section{Ranissini}

The tribe Ranissini is the most primitive tribe of Orgeriinae (Emeljanov, 1980). This tribe is represented by 6 species (from the genera Elysiaca, Sphenocratus, and Ranissus), for which chromosome data are available (Kuznetsova, 1985), in addition to Schizorgerius scytha (firstly recorded data for the genus) and Ranissus edirneus reported here. All the species studied share $2 n=26$ $+\mathrm{X}$. Using mainly meiotic stages and conventional cytological techniques we did not discover any cytological markers that could be used to differentiate the species. It is noteworthy that all the previous data on dictyophrid karyotypes are from meiotic cells, mainly from spermatocyte metaphases I. However the Schizorgerius scytha karyotype reported here is based not only on studying meiotic cells but also oogonial mitotic metaphases. The mitotic metaphases provided additional confirmatory information on the karyotype. An important implication of this is that differential condensation of chromosomes at meiotic metaphase obscures their real relative sizes and can lead to misinterpretation of the karyotype. At metaphase I of Sch. scytha, the largest bivalent (AA1) does not appear to be as long compared to AA2 (the second in size) as indicated in the mitotic cells, where this pair is about four times longer than AA2. Furthermore, only at mitotic metaphase was it noticed that a pair of the longest autosomes of Sch. scytha had NORs located subterminally.

The tribe Ranissini appeared to be monomorphic not only in chromosome complement, but also in 6 follicles per testis, the pattern present in all the species studied.

\section{Orgeriini}

The tribe Orgeriini is one of the most advanced tribes of Orgeriinae, demonstrating a great number of apomorphies (Emeljanov, 1980). Interestingly, Orgerius rhyparus, O. ventosus, and Deserta bipunctata, which are the first cytogenetically studied representatives of this tribe, have $2 n=26+X$ and testes consisting each of 6 follicles. This was unexpected, for both of these patterns indubitably represent an initial state in the subfamily Orgeriinae, inherent in the most primitive tribe Ranissini.

\section{Almanini}

In the tribe Almanini as many as 15 species (from the genera Haumavarga, Nymphorgerius, Orgamarella, Ototettix, Repetekia, Scirtophaca, and Tigrahauda) have been studied hitherto in respect of karyotypes (Table 3). All these species have $2 \mathrm{n}=24+\mathrm{XY}$ in males, as also $B$. cf. gene $i$ in the present study. Their XY sex-determining mechanism appears to be a classic neo-XY system, which can arise only from a system with $\mathrm{X} 0$ male heterogamety by fusion of the $\mathrm{X}$ chromosome with an autosome. The $\mathrm{X}$ chromosome fused with the autosome becomes, conse- quently, neo-X, while the other autosome becomes the socalled neo-Y, the latter being apparently identical with the ancestrally homologous autosomal part of the neo-X chromosome. Thus, neo-XY encountered in Almanini is treated as being derived from the $\mathrm{X} 0$ system characteristic of the primitive tribe Ranissini (Kuznetsova, 1985), and this suggestion agrees well with morphological data (Emeljanov, 1980). Both Bursinia cf. genei and Almana longipes studied here are the first cytogenetically studied representatives of these genera. Although they are close to each other and assigned to the group Almanae, A. longipes unexpectedly has $2 \mathrm{n}=26+\mathrm{X}$, a chromosome complement not previously recorded for the tribe Almanini but characteristic of the tribes Ranissini and Orgeriini. An important point is, however, that the males of $A$. longipes agree with all other Almanini species in having 4 follicles per testis, which as well as $2 \mathrm{n}=24+\mathrm{XY}$ are apomorphic traits of this tribe within the subfamily Orgeriinae (Emeljanov \& Kuznetsova, 1983).

\section{Summary}

In total, chromosome complements of 29 species of the Orgeriinae are currently known. They belong to 17 genera and all tribes except for the African monotypic tribe Collobocini. In the tribes Ranissini and Orgeriini, all the species studied have $2 n=26+X$ whereas in the tribe Almanini all species have $2 \mathrm{n}=24+$ neo-XY with the only exception of $A$. longipes with $2 \mathrm{n}=26+\mathrm{X}$ (Table 3 ).

Emeljanov (1980) has published a well justified phylogeny of the subfamily Orgeriinae, in which the tribe Colobocini is a sister one to Orgeriini + Almanini (Fig. 11a). The transition from Ranissini to higher Orgeriinae is marked by a wide range of morphological transformations - synapomorphies, which are indicative of the monophyly of the Orgeriini, Almanini, and Colobocini. As discussed above, a $2 \mathrm{n}=24+$ neo-XY is indisputably secondary and an autapomorphy of the Almanini while $2 n=26+X$ the ancestral state in the branch Orgeriini + Almanini (Fig. 11a). Until data are available for Colobocini, we can consider another hypothesis, whilst less probable from the morphological point of view, that Colobocini is a sister group to the Almanini (Fig. 11b, c). In that case, $2 \mathrm{n}=24$ $+\mathrm{XY}$ could have evolved either in Almanini (Fig. 11b) or the ancestor of the branch Collobocini + Almanini (Fig. 11c). As to follicle number, in any phylogenetic scenario the transition from 6 to 4 follicles could have occurred once, either in an ancestor of the tribe Almanini (Fig. 11a, b) or the common ancestor of Collobocini + Almanini (Fig. 11c).

As regards $2 \mathrm{n}=26+\mathrm{X}$ of A. longipes, a number of explanations can be offered for the origin of this chromosome complement in the tribe Almanini. One explanation, based on only two males, is that this complement resulted from a polymorphism, such as occurs in Repetekia orbicularis Osh. (Almanini), which has both neo- XY and X0 males (Kuznetsova, 1985). Such a polymorphism has also been described by John \& Claridge (1974) in Oncopsis tristis Zett. (Cicadellidae), where the X0 males predominate but single neo-sex chromosome males are also found. Furthermore, natural populations of another 
Oncopsis species, O. flavicollis L., varied in their mechanism of sex determination: mountain populations are $\mathrm{X} 0$ monomorphic, whereas populations in lowland woodlands are polymorphic and include both X0 and neo-XY males inhabiting different host-plants (Betula $\mathrm{spp}$.) (John \& Claridge, 1974).

We are however inclined to believe that $A$. longipes is monomorphic with $2 \mathrm{n}=26+\mathrm{X}$, thus testifying that Almanini are not karyotypically homogeneous and may yet furnish further examples of the X0 mechanism, since the karyotypes of many genera and species are unknown. The data on $A$. longipes suggest a more complicated karyotype evolution in the tribe Almanini. To explain the presence of two chromosome complements in the tribe Almanini, $2 \mathrm{n}=26+\mathrm{X}$ in $A$. longipes and $2 \mathrm{n}=24+\mathrm{XY}$ in all the rest, we can offer two hypotheses. Emeljanov (1980) considers the group Almanae to be a sister one to the rest of the Almanini (Fig. 12a, b). The monophyly of the group Almanae is supported by a number of reliable morphological synapomorphies (Emeljanov, 1980), as well as by preliminary $16 \mathrm{~S}$ rDNA sequencing data (Emeljanov et al., 2005). Cytogenetic data are currently available only for A. longipes and Bursinia cf. genei. If one assumes that $A$. longipes has inherited its chromosome complement from the Ranissini + Almanini common ancestor, then $2 n=24+X Y$ would have independently originated in the genus Bursinia and the common ancestor of the rest of the Almanini (Fig. 12a). Another approach would be to assume that $2 \mathrm{n}=24+\mathrm{XY}$ originated in the common ancestor of the tribe Almanini, then $2 \mathrm{n}=26+\mathrm{X}$ in the genus Almana would be seen as a reversion (Fig. 12b). We consider the last hypothesis to be much more plausible.

There are two further problems to be discussed here. First, until now neither nucleolus organizer regions (NORs) nor constrictions have been reported for the chromosomes of Dictyopharidae. We have revealed that in Ranissus scytha, Almana longipes, and Deserta bipunctata the largest pair of autosomes have NORs. These species are from three distinct tribes of Orgeriinae, which indicates that this pattern is characteristic at least of this subfamily. Second, whilst there is little information on the number of ovarioles in Dictyopharidae, in every species for which such data are available the number of ovarioles agrees with that of testicular follicles (Table 3). Based on this observation we could suggest the parallel evolution of these structures in Dictyopharidae. It is, however, noteworthy that in other fulgoroid families there is no agreement between the numbers of ovarioles and testicular follicles (Kuznetsova \& Kirillova, 1990; MaryańskaNadachowska et al., 2006).

\section{The ancestral karyotype and possible evolutionary mechanisms underlying the differences in chromosome number in the family Dictyopharidae}

Based on the karyotype diversity found in Dictyopharidae, Kuznetsova (1985) assumed that karyotype evolution in this family occurred predominantly via chromosome fusions. The chromosome complement of $2 n=28+$ $\mathrm{XX} / \mathrm{X0}$ (male/female) in most Dictyopharinae (with
Scolops sulcipes the only exception known at that time) was proposed as the ancestral one, and that of $2 n=26+$ $\mathrm{XX} / \mathrm{X} 0$ in Ranissini and $2 \mathrm{n}=24+\mathrm{XX} / \mathrm{XY}$ in Almanini as derivatives. They were thought to have originated from the ancestral complement of $2 \mathrm{n}=28+\mathrm{XX} / \mathrm{X} 0$ by the consecutive fusions between two pairs of autosomes (resulting in $2 \mathrm{n}=26+\mathrm{XX} / \mathrm{X} 0$ ) and between an autosomal pair and the univalent $X$ chromosome (resulting in $2 n=24+X X / X Y$ where $X Y$ represents a neo-system). It is almost certain that $\mathrm{XX} / \mathrm{X} 0$ sex determination is the ancestral pattern in Dictyopharidae. This is the sex determination that clearly predominates in Auchenorrhyncha as a whole (Kirillova, 1986, 1987) and in the cases of XY males "it is often clear that the $\mathrm{Y}$ is a neo- $\mathrm{Y}$ " (Blackman, 1995: p. 72). The above reasoning leaves the evolutionary sequence of $26+\mathrm{XX} / \mathrm{X} 0 \rightarrow 24+$ neo- XX/XY in Orgeriinae invariant. Consequently, the chromosome complement of $26+\mathrm{XX} / \mathrm{X} 0$ and 6 seminal follicles per testis suggest a "basal" position of Ranissini in the subfamily, and this conclusion is in good agreement with morphological data (Emeljanov, 1980). The same characters found in Orgeriini, are however at variance with the idea (Emeljanov, 1980) that this tribe together with Almanini represent the most advanced taxa within Orgeriinae. On the basis of present knowledge of karyotype and testis structure, we should accept the retention of the ancestral Orgeriinae karyotype and testis structure by the tribe Orgeriini, at least based on the three representatives studied.

As discussed above, the ancestral chromosome complement of Dictyopharinae is currently questionable. Within this subfamily, apart from the clearly derivative $2 n=36+$ $\mathrm{X}$ of Scoloptini, two other chromosome complements, $2 \mathrm{n}$ $=26+\mathrm{X}$ and $2 \mathrm{n}=28+\mathrm{X}$, repeatedly occur in different tribes within a genus or in closely related genera. If the assumption is made that one of these complements is ancestral for Dictyopharinae and the family Dictyopharidae as a whole, we should accept its repeated origin in different genera and tribes. Further interpretation of the ancestral karyotype of the family must wait until more complete cytogenetic knowledge is available, including information on detectable chromosome markers, and comprehensive phylogenies for Dictyopharidae and the whole subfamily Fulgoroidea are elaborated.

ACKNOWLEDGEMENTS. We are grateful to D. Dmitriev for kindly supplying Scolops sulcipes, L. Przybylowicz and M. Kopec for Hyalodictyon taurinum and Trimedia cf. viridata. The study was supported financially by the Russian and Polish Academies of Sciences, the Russian Foundation for Basic Research (Grants 08-04-00787, 08-04-00134), and the Programs of the Presidium of the Russian Academy of Sciences "Gene Pools and Genetic Diversity" and "The Origin and Evolution of Biosphere".

\section{REFERENCES}

Bhattacharya \& Manna 1973: Gonial chromosomes, their behaviour and metrical data in nine species of Fulgorids (Homoptera). Cytologia 38: 281-290. 
BlackMAN R.L. 1995: Sex determination in insects. In Leather S.R. \& Hardie J. (eds): Insect Reproduction. CRC Press, Boca Raton, FL, pp. 57-94.

D'Urso V., Guglielmino A. \& Mauceri A. 2005: The internal male and female reproductive apparatus in Cixidia sikaniae D’Urso \& Guglielmino, 1995 (Fulgoromorpha, Achilidae). Zootaxa 1077: 25-36.

EMELJanov A.F. 1980: Phylogeny and evolution of subfamily Orgeriinae (Homoptera, Dictyopharidae). In: Tshtenija pamjati Cholodkovskovo [Lectures in Memoriam N.A. Kholodkovsky. Vol. 32.] Leningrad, pp. 3-96 [in Russian].

EMELJANOV A.F. 1990: An attempt of construction of phylogenetic tree of the planthoppers (Hemiptera, Cicadina). Entomol. Obozr. 69: 353-356 [in Russian; English transl. in Entomol. Rev. 70: 24-28].

EMELJANov A.F. 2004: A new genus and tribe of Strongylodematinae (Homoptera: Fulgoridae). Zoosyst. Ross. 13(1): 52 .

EMELJANov A.F. 2007: Structure and ways of formation of faunae of the main zoogeographical regions (kingdoms) in the family Dictyopharidae (Homoptera, Fulgoroidea). In: Problems and Perspectives of General Entomology. Abstr. XIII-th Congress of Russian Entomological Society, Krasnodar, September 9-15, 2007. Krasnodar, pp. 103-104 [in Russian].

EMELJANOv A.F. 2008: New genera and species of the family Dictyopharidae (Homoptera), with notes on the systematics of the subfamily Dictyopharinae. Entomol. Obozr. 87(2): 360-396. [in Russian, English abstr.].

Emeljanov A.F. \& Kuznetsova V.G. 1983: The number of seminal follicles as a phylogenetic and taxonomic feature in the Dictyopharidae (Homoptera) and other leafhoppers. Zool. Zh. 62(10): 1583-1586 (in Russian, English abstr.).

Emeljanov A.F., Kuznetsova V.G., Nokkala C. \& NokKala S. 2005: Phylogeny and evolution of the subfamily Orgeriinae (Homoptera, Dictyopharidae). 12-th Intern. Auchenorrhyncha Congress. University of California, Berkeley, August 7-12, 2005. Abstr. of Talks and Posters. pp. 15-16.

Grozeva S. \& Nokkala S. 1996: Chromosome and their meiotic behaviour in two families of the primitive infraorder Dipsocoromorpha (Heteroptera). Hereditas 125: 31-36.

HalkKa L. \& Heinonen L. 1964: The chromosomes of 17 Nearctic Homoptera. Hereditas 52: 77-80.
John B. \& Claridge M. 1974: Chromosome variation in British populations of Oncopsis (Hemiptera: Cicadellidae). Chromosoma (Berl.) 46: 77-89.

KiRILlova V.I. 1986: Chromosome numbers of the leafhoppers (Hemiptera, Auchenorrhyncha) of the world fauna. I. Superfamilies Fulgoroidea, Cercopoidea and Cicadoidea. Entomol. Obozr. 65(1): 115-125 [in Russian; English transl. in Entomol. Rev. 65(4): 34-47].

KiRILlova V.I. 1987: Chromosome numbers of the leafhoppers (Hemiptera, Auchenorrhyncha) of the world fauna. II. Karyotypic peculiarities of the leafhoppers of the superfamily Cicadelloidea. Entomol. Obozr. 66(2): 321-337 [in Russian; English transl. in Entomol. Rev. 67(1): 80-108].

KiRILlova V.I. 1989: The anatomy of the male reproductive system in Homoptera (Cicadina, Delphacidae) and the use of its structure in the taxonomy of the family. Zool. Zh. 68(9): 143-148 [in Russian, English abstr.].

KuZNeTsova V.G. 1985: Phylogenetic analysis of chromosome variability and karyosystematics of Cicadina of the family Dictyopharidae (Homoptera, Auchenorrhyncha). Entomol. Obozr. 64: 539-553. [in Russian; English transl. in Entomol. Rev. 65(2): 88-106].

KuzNetsova V.G. \& Kirillova V.I. 1990. Karyotypes and anatomic characteristics of the reproductive system in the Fulgoroidea (Homoptera, Cicadinea). Zool. Zh. 69(3): 24-31 [in Russian, English abstr.].

Kuznetsova V.G., Maryańska-Nadachowska A., Yang Ch.-Tu \& O'BRIEN L. 1998: Karyotypes, sex-chromosome systems and testis structure in Fulgoroidea (Auchenorrhyncha, Homoptera, Insecta). Folia Biol. (Kraków) 46(1-2): 23-40.

Maryańska-Nadachowska A., Kuznetsova V., Gnezdilov V. \& Drosopoulos S. 2006: Variability in the karyotypes, testes and ovaries of planthoppers of the families Issidae, Caliscelidae, and Acanaloniidae (Hemiptera: Fulgoroidea). Eur. J. Entomol. 103: 505-513.

Tian R., Zhang Y.-L. \& YuAN F. 2004: Karyotypes of nineteen species of Fulgoroidea from China (Insecta: Homoptera). Acta Entomol. Sin. 47: 803-808.

YeH W.-B., YANG C.-T. \& Hui C.-F. 2005: A molecular phylogeny of planthoppers (Homoptera: Fulgoroidea) inferred from mitochondrial 16S rDNA sequences. Zool. Stud. 44: 337-353.

Received August 14, 2008; revised and accepted February 20, 2009 